\title{
MODAL SOSIAL PEMANTIK UNTUK KOTA KREATIF
}

Paper Accepted: 23 Juni 2018 Paper Reviewed: 7-15 Juli 2018 Paper Edited: 17-24 Juli 2018 Paper Approved: 25 Juli 2018

\begin{abstract}
The discussion of this research is the development of creative cities in a country is the result of the efforts of the government and creative actors in the city in the country. Creative city can not be separated from the potential of social capital that is owned by the people in the city. Social capital is a social organization concept that includes network of norms and social trusts that facilitate mutual coordination and cooperation including in developing the regional economy. This research aims to (1) know the contribution of social capital in making a creative city, (2) express the social capital and creativity of individuals and communities to realize creative city, and (3) know aspects of social capital that dominant influence on a creativity of the city. The method of this research is qualitative primary data with technic observation and indepth interview, also secondary data in the form of document and archive analysis from Bandung city as one of creative city in Indonesia. Research is done during 2015-2016. Conclusions this research are (1)Social capital that form trust, tolerance, cooperation, openness, and independence of the community greatly contributes in the creation of creative city because through the braided integration of social capital that forms a norm of behavior binding for its citizens to be creative and does not require material capital,(2)Individual urban creativity formed through the process of socialization of elements of social capital in the life of society to trigger creativity of individuals and society as a whole, and (3) The form of openness, tolerance, and cooperation are the dominant elements of social capital in growing the creativity of individuals and society
\end{abstract}

Keywords: Creatif city, Social capital

\section{PENDAHULUAN \\ Latar Belakang Masalah}

Perkembangan kota kreatif di suatu negara merupakan hasil usaha dari pemerintah dan pelaku kreatif di kota dalam negara tersebut. Pada tahun 2004, UNESCO membentuk program Creative City Network (CCN) untuk kerjasama internasional antar kota yang menempatkan kreativitas sebagai faktor strategis untuk pembangunan berkelanjutan dengan melibatkan semua pihak terkait yaitu pemerintah, swasta, organisasi profesional, komunitas, dan institusi budaya. $\mathrm{CCN}$ memfasilitasi proses pertukaran pengalaman, pengetahuan, dan sumber daya antara anggotanya sebagai jalan untuk mengangkat industri kreatif lokal dan menumbuhkan kerjasama di seluruh dunia dalam pembangunan perkotaan yang berkelanjutan. Tujuan CCN adalah sebagai berikut:

1. Memperkuat penciptaan, produksi, distribusi, dan konsumsi produk dan jasa budaya pada tingkat local

2. Mempromosikan kreativitas dan ekspresi kreatif terutama pada 
kelompok yang rentan, seperti perempuan dan anak muda

3. Meningkatkan akses dan partisipasi pada kehidupan berbudaya termasuk apresiasi terhadap produk budaya

4. Mengintegrasikan industri kreatif dan budaya ke dalam pengembangan lokal.

Pemerintah Indonesia pada tahun 2014 memfasilitasi empat kota yaitu Bandung dan Surakarta sebagai kota desain, Yogyakarta dan Pekalongan sebagai kota craft and folk art untuk dapat secara resmi masuk dalam $\mathrm{CCN}$. Pada akhirnya yang terpilih menjadi bagian dari $\mathrm{CCN}$ adalah Pekalongan sebagai kota craft and folk art serta Bandung sebagai kota desain.

Kota kreatif tidak terlepas dari potensi modal sosial (social capital) yang dimiliki masyarakat di kota tersebut. Modal sosial (Social capital) merupakan konsep organisasi sosial yang meliputi jaringan norma dan kepercayaan sosial yang memfasilitasi koordinasi serta kerja sama yang saling menguntungkan termasuk dalam mengembangkan perekonomian wilayah (Putnam,1995).

Modal sosial merupakan salah satu aspek penting yang menentukan kreatifitas masyarakat. Keberhasilan pembangunan suatu wilayah tidak hanya ditentukan oleh aparat pemerintahnya saja tetapi juga ditentukan oleh masyarakat di wilayah tersebut, termasuk oleh adanya modal sosial yang memacu kreatifitas warganya dalam berbagai hal. Modal sosial dan kreatifitas sangat penting dalam pertumbuhan suatu kota dan perkembangan ekonomi, maka kajian hubungan modal sosial dan penciptaan kreatifitas secara individu maupun masyarakat secara keseluruhan di suatu wilayah sangat penting.

Pemahaman terhadap modal sosial dan kaitannya dengan kreatifitas kota dari beragam sudut pandang akan mendukung kreatifitas suatu kota dan dampak-dampak yang dapat ditimbulkannya. Apabila modal sosial berhasil terbangun dengan baik, maka akan menciptakan masyarakat mandiri yang mampu berpartisipasi dalam peningkatan kesejahteraan wilayah.

Dengan kata lain, semakin tinggi potensi modal sosial maka akan semakin tinggi pula peluang keberhasilan ekonomi (output dan outcome) yang dicapai. Artinya, semakin tinggi modal sosial yang terbangun/terbentuk akan semakin tinggi pula peluang peningkatan produktifitas. Selain itu, semakin tinggi potensi modal sosial akan semakin dinamis kegiatan di dalam kelompok kelompok masyarakatnya.

\section{Perumusan Masalah}

Beberapa pertanyaan agar perumusan masalah tidak melebar dari konteks permasalahan yaitu

1) Apakah modal sosial berkontribusi dalam menjadikan suatu kota kreatif.

2) Bagaimanakah peran modal sosial dan kreatifitas individu serta masyarakat untuk mewujudkan kota kreatif.

3) Apa sajakah aspek-aspek modal sosial yang dominan berpengaruh terhadap suatu kreatifitas kota

\section{Tujuan Penelitian}

Penelitian ini bertujuan untuk

1. Mengetahui kontribusi modal sosial dalam menjadikan suatu kota kreatif.

2. Mengungkapkan modal sosial dan kreatifitas individu serta masyarakat untuk mewujudkan kota kreatif.

3. Mengetahui aspek-aspek modal sosial yang dominan berpengaruh terhadap suatu kreatifitas kota

\section{Manfaat Penelitian}

Hasil penelitian ini diharapkan dapat memberikan sumbangan pengetahuan mengenai faktor-faktor modal sosial yang dapat mempengaruhi. kreatifitas kota.

\section{KAJIAN PUSTAKA}

\section{Modal Sosial}

Modal sosial dapat berfungsi ekonomi dengan bentuk mengefisienkan biaya transaksi koordinasi formal seperti kontrak, aturan birokrasi, dan sejenisnya (Putnam, 1995). Selain itu, Pierre Bourdie (1986) mendefinisikan modal sosial adalah aspek sosial dan budaya yang memiliki nilai ekonomi dan dapat dilembagakan, meliputi keseluruhan sumber daya berupa akal maupun potensi sosial yang terkait dengan kepemilikan jaringan hubungan kelembagaan yang tetap dengan didasarkan pada saling kenal dan mengakui.

Colemann (1999) menyatakan modal sosial adalah kewajiban dan harapan, saluran-saluran informasi dan norma-norma sosial. Modal sosial merupakan kemampuan kerja bersama menghadapi seluruh permasalahan, untuk mencapai tujuan dalam kelompok atau organisasi. Menurut Burt (1992), modal sosial merupakan kemampuan masyarakat untuk berasosiasi berhubungan antara satu dengan yang lainnya dan selanjutnya menjadi kekuatan penting dalam ekonomi dan aspek eksistensi sosial lainnya. 
Hasbullah (2006) menjelaskan bahwa modal sosial merupakan segala sikap dalam masyarakat yang secara bersama-sama menuju kepada kemajuan dan perubahan yang pada dasarnya ditopang oleh norma-norma seperti kepercayaan dan toleransi, sedangkan menurut Solow (1999), modal sosial merupakan serangkaian nilai-nilai atau norma-norma yang diwujudkan dalam perilaku yang dapat mendorong kemampuan dan kapabilitas untuk bekerjasama dan berkoordinasi untuk menghasilkan kontribusi besar terhadap keberlanjutan produktivitas. Menurut Rusdi Syahra (2003) terdapat sepuluh unsur modal social yaitu

1. Kepercayaan (trust) adalah kecenderungan untuk menepati suatu yang telah dikatakan secara lisan ataupun tulisan,

2. Solidaritas, kesediaan untuk secara sukarela menanggung suatu konsekuensi sebagai wujud adanya rasa kebersamaan dalam menghadapi suatu masalah,

3. Toleransi, kesediaan untuk memberikan konsensi atau kelonggaran dalam bentuk materi maupun non materi sepanjang tidak berkenaan dengan hal-hal yang bersifat prinsip dalam hidupnya,

4. Tanggung jawab adalah kesadaran untuk memenuhi kewajiban sebagai cerminan rasa peduli terhadap masalahmasalah yang menyangkut kepentingan bersama,

5. Kerja sama adalah suatu keadaan yang mencerminkan kesediaan dari semua pihak yang terlibat memberikan kontribusi yang seimbang dalam melakukan berbagai hal yang menyangkut kepentingan bersama,

6. Kebersamaan adalah sikap dan perilaku yang mencerminkan adanya kesediaan untuk terlibat dalam kegiatan yang menyangkut kepentingan bersama,

7. Kemandirian adalah sikap dan perilaku yang mengutamakan kemapuan sendiri untuk memenuhi berbagai kebutuhan tanpa tergantung kepada atau mengharapkan bantuan orang lain,

8. Keterbukaan adalah kesediaan menyampaikan secara apa adanya segala hal yang orang lain berkepentingan mengganggap bahwa mereka perlu mengetahuinya,

9. Keterusterangan adalah kesediaan untuk menyampaikan secara apa yang sesungguhnya dipikirkan atau dirasakan tanpa dihalangi oleh perasaan enggan atau takut,

10. Empati adalah kemampuan memahami apa yang dirasakan oleh orang lain atau kemampuan untuk menempatkan diri dalam situasi orang lain

Sudut Pandang Modal Sosial dalam Ekonomi

Filer (1985) mengemukakan bahwa dalam aspek ekonomi, modal sosial merupakan aktivitas non pasar yang berimplikasi langsung terhadap proses ekonomi, yakni meningkatnya pendapatan (income real). Menurut Fukuyama (1995), modal sosial berbeda dengan modal manusia (Human Capital) ditinjau secara definisi maupun terminologi.

Bentuk human capital meliputi pendidikan dan keterampilan pada manusia, sedangkan modal sosial merupakan kapabilitas yang muncul dari kepercayaan masyarakat umum atau kelompok-kelompok kecil di dalam menunjang proses kehidupan ekonomi maupun non ekonomi. Lebih lanjut dalam sudut pandang ekonomi, menurut Adam Smith dalam W.I.M Poli (2011), dalam bukunya berjudul "The Theory of Moral Sentiments" mengemukakan tiga kecenderungan moral dalam diri manusia yang harus dicegah supaya manusia tidak bertindak berlebih lebihan dalam usaha mencapai keuntungan pribadinya secara rasional.

Tiga kecenderungan moral yang bukan merupakan suatu modal sosial adalah: a) Cinta kepada diri sendiri dan kurang simpati kepada orang lain (Self-love \& no sympathy), b) Keinginan untuk bebas dari keterkaitan pada rasa sopan santun terhadap orang lain (The desire to be free toward sense of proprierty), dan c) Kebiasaan untuk bekerja menghasilkan apa yang dibutuhkan sendiri dan kecenderungan untuk mengadakan pertukaran hasil produksi sendiri dengan hasil produksi orang lain (The habit of labour and propensity to exchange ).

Dari kecenderungan di atas dapat dilihat bahwa moral berperan sangat penting bagi nilai ekonomi. Dapat diartikan pula bahwa dimensi moral tercipta pada kehidupan sosial melalui hubungan antara individu dalam masyarakat. Atas dasar hal ini dapat ditarik kesimpulan bahwa ekonomi ada di dalam masyarakat, sedangkan di dalam masyarakat terdapat individu dan di dalam masing masing individu tersebut terdapat moral. Moral inilah yang merupakan modal sosial suatu masyarakat meraih peluang ekonomi. 


\section{Kota Kreatif}

Landry dan Bianchini (1995) menjelaskan gagasan konsep kota kreatif yang merupakan respon terhadap permasalahan urban yang dihadapi oleh beberapa kota di dunia saat terjadi transisi ekonomi. Konsep kota kreatif adalah memperbaiki lingkungan urban dan menciptakan atmosfir kota yang inspiratif dan juga sebagai arah gerak perkembangan kota tersebut. Penerapan gagasan kota kreatif sebenarnya telah dimulai di kota-kota di negara Inggris, dan kemudian menyebar ke Eropa dan Amerika sebagai akibat terjadinya resesi dan krisis ekonomi yang menyebabkan kebangkrutan sektor industri.

Kota-kota industri di wilayah tersebut yang perekonomian utamanya didukung dari sektor manufaktur tidak mampu menghadapi krisis yang ada dan berupaya melakukan transformasi dari kota yang bergantung kepada sektor industri ke kota yang bergantung kepada kreatifitas penduduknya.

Jumlah penduduk yang meningkat di perkotaan akan memunculkan berbagai permasalahan yang timbul. Namun dapat juga terjadi sebaliknya bahwa jumlah penduduk yang besar juga merupakan potensi yang harus dimanfaatkan dalam rangka pembangunan kota. Jumlah penduduk yang besar yang disertai dengan modal sosial yang tinggi sangat berpotensi untuk menghasilkan suatu kreatifitas penduduk.

Berdasarkan beberapa penelitian yang telah dilakukan tampak bahwa modal sosial sangat berperan dalam memunculkan aktivitasaktivitas dalam kehidupan sosial, ekonomi maupun budaya dan dalam menghasilkan barang (goods), jasa (services) maupun prestasi (achievement).

Modal sosial diyakini sebagai komponen yang sangat penting dalam menggerakkan kebersamaan, mobilitas ide, rasa saling percaya, dan saling menguntungkan. Landry (2006) juga menyatakan pentingnya lingkungan kota yang dapat mendukung kegiatan kreatif masyarakatnya dengan menyediakan apa yang mereka butuhkan.

Oleh karena itu, untuk menciptakan atmosfer kota yang inspiratif dibutuhkan dukungan berupa lingkungan psikis dan lingkungan fisik dimana masyarakat dapat berkreativitas dengan optimal. Lingkungan psikis terkait dengan sikap sosial yaitu dukungan dan toleransi terhadap kreativitas dari pemerintah kota dan masyarakat dalam mewujudkan kota kreatif, sedangkan lingkungan fisik terkait dengan fasilitas atau ruang yang mewadahi kegiatan manusia berkreativitas.

Lingkungan yang inspiratif dapat mempengaruhi kegiatan manusia karena manusia menjadi merasa nyaman dan terdorong untuk mengeluarkan ide-ide kreatifnya.

\section{METODOLOGI}

Data primer kualitatif dengan teknik pengumpulan data berupa observasi dan wawancara secara mendalam (indepth interviewing )serta data sekunder berupa analisis dokumen dan arsip dari kota Bandung sebagai salah satu kota kreatif di Indonesia dilakukan selama tahun 2015-2016.

Modal sosial yang dikaji dalam penelitian ini adalah sebagian (5) modal sosial yang dikaji oleh Rusdi Syahra (2003) yaitu 1) Kepercayaan (trust) yaitu kecenderungan untuk menepati sesuatu yang telah dikatakan secara lisan ataupun tulisan, 2) Toleransi yaitu kesediaan untuk memberikan konsensi atau kelonggaran dalam bentuk materi atau non materi sepanjang tidak berkenaan dengan hal-hal yang bersifat prinsip, 3) Kerja sama yaitu suatu keadaan yang mencerminkan kesediaan dari semua pihak yang terlibat memberikan kontribusi yang seimbang dalam melakukan berbagai hal yang menyangkut kepentingan bersama, 4) Keterbukaan yaitu kesediaan menyampaikan secara apa adanya segala hal yang orang lain berkepentingan mengganggap bahwa mereka perlu mengetahuinya, dan 5) Kemandirian adalah sikap dan perilaku yang mengutamakan kemampuan sendiri untuk memenuhi berbagai kebutuhan tanpa tergantung kepada atau mengharapkan bantuan orang lain. Pertimbangan pemilihan lima unsur modal sosial adalah arti penting modal sosial tersebut mewakili modal sosial lainnya.

\section{HASIL DAN PEMBAHASAN}

\section{Kepercayaan (trust)}

Kepercayaan terhadap seseorang mempengaruhi pelaksanaan kegiatan usaha yang sedang dilakukannya. Hal ini berkaitan dengan resiko kegagalan usaha, karena investor yang memiliki kepercayaan lebih tinggi akan lebih mengetahui situasi dan kondisi usaha yang dihadapi, sehingga kegagalan usaha dapat dihindari (Adiwilaga, 1990).

Kepercayaan adalah suatu hal yang dilakukan oleh suatu pihak yang dapat dibenarkan oleh pihak lain. Kepercayaan merupakan kunci awal,, pondasi yang harus ada dalam hubungan kedua belah pihak agar tercipta suatu hubungan yang harmonis. Kepercayaan 
diberikan kepada seseorang yang dinilai mampu serta bijak dalam menjalankan serta memegang kepercayaan tersebut.

Kepercayaan masyarakat kepada investor dianggap mampu meningkatkan kesejahteraan hidup masyarakat sehingga akan memacu peningkatan kreatifitas dalam kehidupan masyarakat tersebut. Kepercayaan yang diberikan kepada suatu pihak merupakan amanah yang harus selalu dijaga, sehingga apa yang diharapkan sesuai dengan harapan bersama.

Kepercayaan merupakan faktor pendorong timbulnya kreatifitas. Jika kepercayaan yang telah diberikan kepada salah satu pihak disalahgunakan, maka dapat menimbulkan dampak yang tidak diharapkan di antaranya hubungan kerja akan berakhir, jaminan nama baik akan hancur dan kerugian harus ditanggung oleh kedua belah pihak yang berhubungan. Menjaga kepercayaan bukan suatu yang ringan, tetapi apapun bentuknya suatu kepercayaan harus dilakukan dengan bijak dan penuh tanggung jawab.

$$
\text { Beberapa perilaku yang dapat }
$$

meningkatkan kepercayaan dalam suatu hubungan di antaranya: transparan (tidak menyembunyikan agenda dan rencana tertentu untuk keuntungan satu pihak saja), tulus (tidak mengelabui pihak lain dengan kata-kata pujian palsu atau pura-pura memberi dukungan karena ketika satu pihak mengetahui bahwa pihak lain tulus maka kepercayaan akan meningkat kepada pihak tersebut), fokus kepada penambahan nilai (kedua belah pihak menfokuskan pada tindakan-tindakan untuk memberi nilai tambah kepada kehidupan kedua belah pihak), hadir dengan seluruh jiwa raga (kedua belah pihak memberikan waktu yang berkualitas agar terbentuk kepercayaan), memperlakukan pihak lain dengan hormat supaya terjadi peningkatan kepercayaan (pengaruh lingkungan dapat melunturkan perilaku hormat bahkan satu pihak meremehkan pihak lain), bertanggung jawab atas perbedaan yang dilakukan akan membentuk kepercayaan dari pihak lain, fokus kepada umpan balik (kepercayaan tidak hanya pasif menunggu pihak lain memberi umpan balik yang bernilai positif maupun negatif dan mengubah semua kebiasaan yang kurang baik berdasarkan umpan balik tersebut), menerima kritikan dengan baik (menutup diri dari kritikan akan berdampak menutup kepercayaan dan komunikasi), berbudi bahasa yang baik menjadi dasar kepercayaan, memegang janji lebih kuat dibandingkan dengan kontrak tertulis apapun (membuat janji kosong.akan mengurangi kepercayaan), konsistensi (kunci untuk menjaga kepercayaan kedua belah pihak). Kepercayaan terbukti menjadi modal sosial terhadap kreatifitas terbentuknya komunitas desain yang berkembang di kota Bandung.

\section{Toleransi}

Modal sosial suatu kota kreatif adalah terdapatnya toleransi yang tinggi antara warga asli terhadap orang yang berasal dari luar kota. Toleransi diartikan sebagai pemberian kebebasan kepada sesama warga masyarakat untuk menjalankan hidupnya dan menentukan nasibnya masing-masing selama di dalam menjalankan dan menentukan sikapnya itu tidak bertentangan dengan syarat-syarat atas terciptanya ketertiban dan perdamaian dalam masyarakat. Toleransi masyarakat berupa kesediaan untuk memberikan kelonggaran dalam bentuk materi maupun non materi asalkan tidak melenceng dari adat kebiasaan hidupnya sangat diperlukan.

Pemeliharaan toleransi tidak hanya menjadi kewajiban masyarakat kota tetapi juga menuntut kesediaan dari pemegang otoritas kebijakan (pemerintah). Hal ini sesuai dengan pernyataan Hartley et al. (2012) yang menyatakan bahwa salah satu dimensi kota kreatif adalah terdapatnya toleransi terhadap keragaman yang ada, bahkan Desmon Hui (2004) menyatakan luaran kreatifitas(outcomes of creativity) tidak terlepas dari adanya toleransi terhadap perbedaan dan menerima orang yang berasal dari luar. Toleransi tidak hanya mencakup sikap terhadap perbedaan, tetapi juga mencakup toleransi dalam menanggung konsekuensi yang mungkin timbul dari adanya kreatifitas masyarakatnya.

Tumbuh dan berkembangnya toleransi dalam sebuah masyarakat kota tidak dapat dilepaskan dari struktur sosial dan budaya masyarakat yang bersangkutan. Kebudayaan masyarakat yang menjunjung tinggi sikap toleransi tidak terbentuk secara tiba-tiba dan instant tetapi sudah dilembagakan/dibiasakan dalam masyarakat tersebut sejak seseorang masih kecil.

Dengan demikian, proses pelembagaan nilai-nilai toleransi dalam masyarakat memerlukan waktu yang lama untuk dijadikan sebagai norma yang mengatur perilaku seorang anggota masyarakat. Terbentuknya sikap toleransi pada setiap individu anggota masyarakat akan menjiwai individu tersebut dalam menerima perbedaan yang terjadi, seperti halnya masyarakat Bandung yang toleran terhadap investor yang datang membawa kreatifitasnya. Keragaman kreatifitas yang 
masuk ke kota Bandung justru memantik kreatifitas masyarakat asli Bandung.

\section{Kerjasama}

Kerjasama mencakup kesamaan paradigma, kesepakatan dan berlawanan dengan sifat kompetisi. Kerjasama sebagai bentuk yang ideal untuk pengelolaan urusan perorangan dan/atau kelompok dalam pencapaian tujuannya. Terbentuknya Bandung sebagai kota kreatif di Indonesia berbeda dengan skenario city planing di London Inggris. Proses terbentuknya London sebagai kota kreatif atas dasar inisiatif pemerintah dengan penyediaan pendanaan yang besar untuk melandasi masalah infrastruktur.

Terbentuknya Bandung kota kreatif berdasarkan kearifan lokal berupa modal sosial kerja sama yang dimilikinya yang terjalin di antara sesama pelaku kreatif. Kerjasama biasanya dibentuk karena terdapat unsur yang tidak dimiliki oleh salah satu pihak tetapi dimiliki oleh pihak lain. Selain itu, kerjasama juga tercipta ketika berbagai pihak yang terlibat memiliki suatu tujuan yang sama untuk mencapainya.

Soerjono Soekanto (1983) menyatakan bahwa untuk terciptanya kerjasama seringkali harus ada faktor bersama yang dimiliki oleh pihak-pihak yang mau bekerjasama, kepentingan yang sama, karakteristik dan latar belakang yang sama, dan pencapaian suatu tujuan yang tidak dapat dicapai melainkan harus melalui cara kerjasama.

Menurut Rusdi Syahra (2003), kerjasama sebagai suatu keadaan yang mencerminkan kesediaan dari semua pihak yang terlibat memberikan konstribusi yang seimbang dalam melakukan berbagai hal yang menyangkut kepentingan bersama merupakan salah satu unsur modal sosial yang penting dalam menumbuh kembangkan kreatifitas. Kerjasama yang dilakukan pada akhirnya dapat menimbulkan rasa kebersamaan dari berbagai pihak yang terlibat.

Kebersamaan dalam mencapai suatu tujuan sangat penting karena tidak semua yang diinginkan dapat dicapai dengan melakukannya sendiri, termasuk dalam hal mewujudkan suatu kreatifitas.

Sebagai contoh, terdapatnya berbagai taman di kota Bandung dengan berbagai fungsinya seperti taman jomblo, taman film, taman atletik, taman lansia, taman superhero merupakan bentuk hasil kerjasama dari berbagai pihak dalam rangka menampilkan kota Bandung yang indah, ramah, kreatif, dan nyaman. Bentuk taman yang beraneka ragam yang dijumpai di kota ini tidak hanya melibatkan seniman untuk desainnya, tetapi juga melibatkan pihak akademisi landscape untuk menentukan kelayakan tempat/wilayahnya serta dukungan pemerintah untuk mewujudkannya melalui alokasi tata ruang dan pendanaannya.

\section{Keterbukaan}

Menurut Soerjono Soekanto (1983), salah satu faktor pendorong terjadinya perubahan dalam masyarakat adalah dimilikinya sikap terbuka terhadap dunia luar. Selain itu, tingkat pendidikan masyarakat, keinginan untuk merubah nasib, dan struktur sosial yang tidak kaku juga merupakan faktor pendorong terhadap mudahnya suatu masyarakat menerima perubahan. Hartley et al (2012) menyatakan bahwa salah satu dimensi dari delapan dimensi kota kreatif adalah adanya keterbukaan dari masyarakatnya. Begitu juga dengan Desmon Hui (2004) yang menyatakan bahwa luaran kreatifitas tidak terlepas dari sikap terbuka terhadap penerimaan orang yang berasal dari luar.

Dengan demikian peranan keterbukaan terhadap kreatifitas suatu kota sangat penting selain faktor-faktor lainnya seperti ketertarikan dan perhatian terhadap ekonomi, dukungan publik, partisipasi dalam organisasi sosial, dan lain-lain.

Terbukanya masyarakat kota Bandung (terutama kaum mudanya) terhadap inovasi baru dan kreatifitas baru yang dibawa oleh orang yang berasal dari luar kota Bandung untuk disebarluaskan di kota Bandung terlihat pada contoh kreatifitas kerajinan tangan melalui pengenalan inovasi batik dari Cirebon dari luar kota Bandung dapat dengan mudah dipadu padankan dengan jeans produk Bandung menjadi desain baju kreatif oleh masyarakat kota Bandung.

Kreatifitas itu menarik dan memberikan tambahan penghasilan sehingga pelaku kreatifitas kota Bandung akan dengan mudah meminta dikenalkan dan diajarkan bentuk kreatifitas baru tersebut tanpa penambahan biaya pelatihan membatik.

\section{Kemandirian}

Kemandirian masyarakat kota Bandung dalam kreatifitas telah dikenal luas. Kemandirian dalam menciptakan model-model fashion, kemandirian dalam penyelenggaraan suatu event, kemandirian dalam menciptakan model-model baru kuliner melalui pengolahan bahan dan cara yang dilakukan, dan kemandirian dalam menciptakan bentuk-bentuk 
kreatifitas baru kerajinan tangan juga telah dikenal luas.

Dengan demikian walaupun kemandirian dalam hal pembiayaan kreatifitas membatasi berkembangnya kreatifitas tersebut namun hal ini disisi lain dapat diatasi dengan menciptakan bentuk-bentuk kreatifitas baru dengan memperhatikan sumber modal yang terbatas tersebut.

Keterbatasan dalam pembiayaan suatu kreatifitas ternyata telah melahirkan kreatifitas baru dalam menyiasati keterbatasan tersebut, yaitu dengan menyesuaikan bentuk kreatifitas yang dihasilkan. Selain itu, keterbatasan dalam hal pembiayaan ternyata telah memunculkan kreatifitas menjalin kerjasama dengan pihak luar, termasuk pihak luar negeri, dalam mewujudkan suatu kreatifitas yang diinginkan.

\section{PENUTUP}

\section{Kesimpulan}

1. Modal sosial berbentuk kepercayaan, toleransi, kerjasama, keterbukaan, dan kemandirian dari masyarakat sangat berkonstribusi dalam pembentukan kota kreatif karena melalui jalinan keterpaduan modal sosial yang membentuk sebuah norma perilaku yang mengikat bagi warganya untuk kreatif dan tidak memerlukan input modal materi.

2. Kreatifitas individu masyarakat kota terbentuk melalui proses sosialisasi unsurunsur modal sosial dalam kehidupan masyarakat sehingga memantik kreatifitas individu dan masyarakat secara keseluruhan.

3. Dari lima unsur modal sosial yang diamati, tampak bahwa unsur modal sosial berupa keterbukaan, toleransi, dan kerjasama merupakan unsur modal sosial yang dominan dalam menumbuh kembangkan kreatifitas individu dan masyarakat.

\section{DAFTAR PUSTAKA}

Colleman, James. (2006). Social Capital In The Creation of Capital In The Creation of Human Capital. Washington DC: The World Bank

Desmon, Hui. (2004). “A Study On Creativity Index" Centre for Cultural Policy Research. The University Of Hongkong.

Fukuyama, Francis, (terj.Ruslani). (2002). "Trust, Kebajikan Sosial dan Penciptaan Kemakmuran". Yogyakarta: Penerbit Qalam.

Hartley, J. Potts, J. MacDonal, T. Erkunt, C. Kufleitner, C. (2012). "CCI Creative Index City". ARC Centre of Excellence for Creative Industries and Inovation. Australia

Hasbullah, J., (2006). "Sosial Kapital: Menuju Keunggulan Budaya Manusia Indonesia". Jakarta: MR-United Press.

Landry, C dan Bianchini, F. (1995). "The Creative City". Comedia

Landry, C. (2006). "The Art of City Making". London. Earthscan

Munandar, Sulaeman, dan Homzah, Siti. (2012). "Pengembangan (Modifikasi) Teori Modal Sosial dan Aplikasinya yang Berbasis Masyarakat Petani Peternak: Studi Kasus Pendekatan Sosiologis Pada Kelompok dan Organisasi Usaha Tani Ternak Sapi Perah di Kecamatan Pangalengan Kabupaten Bandung”. Universitas Padjadjaran Bandung.

Munandar, Sulaeman. (2004). "Resolusi Konflik Model Pemberdayaan Modal Sosial Sebagai Alternatif Pencegahan Konflik Tawuran Antar Desa (Kasus Pada Masyarakat Desa Kabupaten Indramayu Jawa Barat)". Dikti Penelitian Hibah Bersaing P3M Jakarta

Syahra, Rusdi. (2003). "Modal Sosial: Konsep dan Aplikasi". Jurnal Masyarakat dan Budaya Volume.5 No.1. 2003. LIPI Jakarta 